\title{
Straw incorporation increases crop yield and soil organic carbon sequestration but varies under different natural conditions and farming practices in China: a system analysis
}

\author{
Xiao Han ${ }^{1, *}$, Cong Xu ${ }^{1, *}$, Jennifer A. J. Dungait ${ }^{2}$, Roland Bol ${ }^{3}$, Xiaojie Wang ${ }^{1}$, Wenliang $\mathrm{Wu}^{1}$, and Fanqiao Meng ${ }^{1}$ \\ ${ }^{1}$ Beijing Key Laboratory of Biodiversity and Organic Farming, College of Resources and Environmental Sciences, \\ China Agricultural University, Beijing, 100193, China \\ ${ }^{2}$ Sustainable Agriculture Sciences, Rothamsted Research, North Wyke, Okehampton, Devon EX20 2SB, UK \\ ${ }^{3}$ Institute of Bio- and Geosciences, Agrosphere Institute (IBG-3), Forschungszentrum Jülich GmbH, \\ 52425 Jülich, Germany \\ *These authors contributed equally to this work.
}

Correspondence: Fanqiao Meng (mengfq@cau.edu.cn)

Received: 18 November 2017 - Discussion started: 21 November 2017

Revised: 22 February 2018 - Accepted: 4 March 2018 - Published: 3 April 2018

\begin{abstract}
Loss of soil organic carbon (SOC) from agricultural soils is a key indicator of soil degradation associated with reductions in net primary productivity in crop production systems worldwide. Technically simple and locally appropriate solutions are required for farmers to increase SOC and to improve cropland management. In the last 30 years, straw incorporation (SI) has gradually been implemented across China in the context of agricultural intensification and rural livelihood improvement. A meta-analysis of data published before the end of 2016 was undertaken to investigate the effects of SI on crop production and SOC sequestration. The results of 68 experimental studies throughout China in different edaphic conditions, climate regions and farming regimes were analyzed. Compared with straw removal (SR), SI significantly sequestered SOC $(0-20 \mathrm{~cm}$ depth $)$ at the rate of 0.35 (95\% CI, 0.31-0.40) $\mathrm{Mg} \mathrm{Cha}^{-1} \mathrm{yr}^{-1}$, increased crop grain yield by $13.4 \%(9.3-18.4 \%)$ and had a conversion efficiency of the incorporated straw $\mathrm{C}$ of $16 \% \pm 2 \%$ across China. The combined SI at the rate of $3 \mathrm{Mg} \mathrm{Cha}^{-1} \mathrm{yr}^{-1}$ with mineral fertilizer of $200-400 \mathrm{~kg} \mathrm{Nha}^{-1} \mathrm{yr}^{-1}$ was demonstrated to be the best farming practice, where crop yield increased by $32.7 \%(17.9-56.4 \%)$ and SOC sequestrated by the rate of $0.85(0.54-1.15) \mathrm{MgCha}^{-1} \mathrm{yr}^{-1}$. SI achieved a higher SOC sequestration rate and crop yield increment when applied to clay soils under high cropping intensities, and in areas such as northeast China where the soil is being degraded. The SOC responses were highest in the initial start-
\end{abstract}

ing phase of SI, then subsequently declined and finally became negligible after 28-62 years. However, crop yield responses were initially low and then increased, reaching their highest level at 11-15 years after SI. Overall, our study confirmed that SI created a positive feedback loop of SOC enhancement together with increased crop production, and this is of great practical importance to straw management as agriculture intensifies both in China and other regions with different climate conditions.

\section{Introduction}

Around a quarter of China's land territory (or $>2$ million $\mathrm{km}^{2}$ ) is affected by soil degradation associated with the loss of net primary productivity equating to $\sim 60$ billion $\mathrm{Mg}$ carbon (C) over 23 years (Bai et al., 2008). The considerable impact of soil degradation on crop production in China and worldwide points to the need for solutions appropriate to location-specific agro-ecological conditions and farming systems (Bindraban et al., 2012). Soil organic carbon (SOC) loss is a key indicator of soil degradation that is accelerated by land use (Erb et al., 2016; Liu et al., 2018) and is widely associated with cultivation (Dungait et al., 2012; Amundson et al., 2015). Thus, management to enhance SOC to potentially rejuvenate degraded agricultural soils, thereby improving soil fertility and increasing crop yield (Smith et al., 
2012), while sequestering soil $\mathrm{C}$ to mitigate climate change (Meinshausen et al., 2009) is a win-win scenario that maintains the integrity of agricultural ecosystems (Power, 2010).

Like many degraded arable soils across the world, cropland soils in China commonly have low SOC (12.0$12.7 \mathrm{~g} \mathrm{~kg}^{-1}$ at $0-20 \mathrm{~cm}$; Yan et al., 2011), which suggests a substantial potential for $\mathrm{C}$ sequestration (25-37 billion $\mathrm{Mg}$

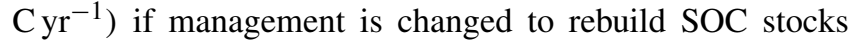
in cultivated soil (Lal, 2002). Since the start of the reform policies in 1978, China has experienced a rapid agricultural intensification process, which was characterized by farming practices mostly involving a high mineral fertilization rate (e.g., $>400 \mathrm{~kg} \mathrm{~N} \mathrm{ha}^{-1} \mathrm{yr}^{-1}$; Ju et al., 2004), frequent irrigation events (Kong et al., 2016) and popularized mechanization (X. Zhang et al., 2017). This process greatly increased not only the grain yield but also straw yield to $>0.6$ billion $\mathrm{Mg}$ straw $\mathrm{yr}^{-1}$ (Shi et al., 2014). Crop straw was once widely harvested for fuel but with the improvement in rural livelihoods after the 1990s, farmers have tended to switch to electricity, liquid gas or coal (X. Zhang et al., 2017), introducing challenges for managing large amounts of "waste" straw (Kong et al., 2014). The recently renewed recognition of SOC for soil health and quality has encouraged straw incorporation (SI) as a simple and environmentally friendly measure to effectively enhance cropland SOC levels (Pan et al., 2010; Liao et al., 2015) and to improve crop production (Zhao et al., 2015).

Differences in climatic and edaphic conditions (Bolinder et al., 2007), fertilization strategies (Khan et al., 2007), cropping regimes (Huang et al., 2012) and duration of SI (Lehtinen et al., 2014) have resulted in large spatial and temporal variations in the effects of SI on SOC and crop yield in China (Li et al., 2003; Yu et al., 2012). Extensive field experiments covering different regions and under various farming systems have been conducted since the 1980s to study the effect of SI (e.g., Cai and Qin, 2006; Gong et al., 2009; Zhang et al., 2014). Integration of the results of these studies assists an effective examination of the underlying mechanisms of SI on SOC (e.g., SOC conversion efficiency; Kong et al., 2005; Wang et al., 2015) and crop yield. This novel information could also provide scientific support for the development of sound policies for straw management at regional and governmental levels (Ministry of Agriculture-PRC., 2013, 2015).

We conducted a meta-analysis to test the hypothesis that SI increases SOC stocks and crop yields in China because it is an effective and proven statistical method to quantitatively integrate the results of numerous individual studies and subsequently draw general conclusions at a larger scale (Gurevitch et al., 2001; Chivenge et al., 2011). To date, several meta-analyses have reported on the effects of SI on SOC or crop yield in China's arable soils (e.g., Lu et al., 2009; Tian et al., 2015; Wang et al., 2015; Zhao et al., 2015). For instance, $\mathrm{Lu}$ et al. (2009) reported that SI could sequester 9.76 billion $\mathrm{Mg} \mathrm{Cyr}^{-1}$ in China's cropland and Zhao et al. (2015) found that SI improved crop yield by $7 \%$ across China. How-

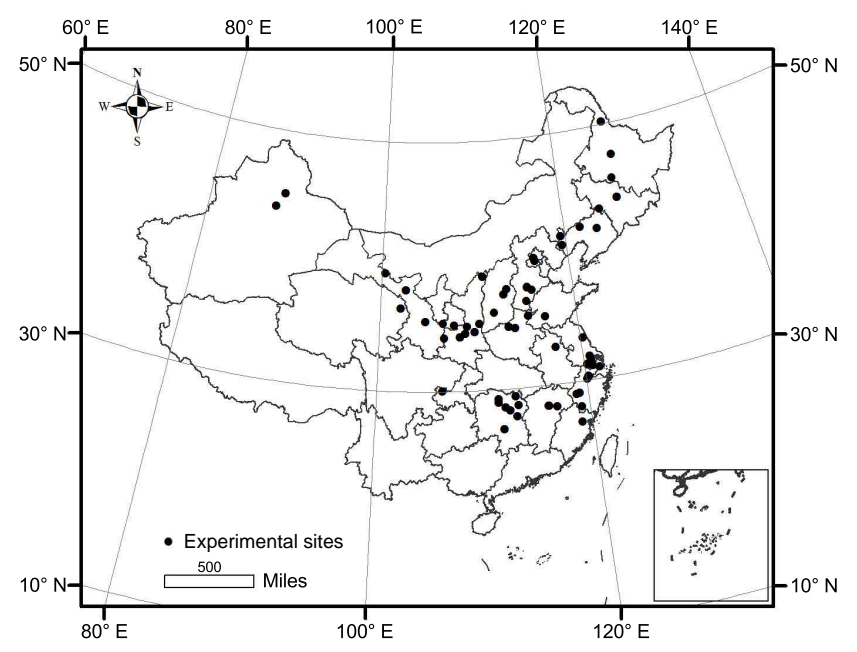

Figure 1. Locations of the long-term experiment sites in the study area.

ever, only a few of these studies presented the effects of SI in different climatic and edaphic regions (Lu et al., 2009; Zhao et al., 2015), or addressed both the responses of crop yield and SOC to SI (Wang et al., 2015). The poor reporting of straw C conversion efficiencies (Lu et al., 2009; Tian et al., 2015) also weakens the practicability of related conclusions in policy development. To overcome these limitations in previous meta-analysis studies, we conducted a new meta-analysis for field experiments carried out over the last 30 years in China. We aimed to (i) quantify the responses of SOC and crop yield to SI at regional and national scales, (ii) calculate the conversion efficiency of straw $\mathrm{C}$ to SOC and (iii) assess the effects of major factors of soil properties (e.g., texture and initial SOC content), climate conditions (temperature and precipitation) and farming practices (e.g., straw quantity and type, incorporation duration, $\mathrm{N}$ fertilizer and cropping system) on the efficacy of SI.

\section{Materials and methods}

\subsection{Data source}

A survey of peer-reviewed papers published before 31 December 2016 was conducted using two bibliographic databases: the Web of Knowledge and the Chinese Journal Databases (CNKI). The keywords "soil organic carbon", "straw incorporation" and "straw return" were used. To be included in the meta-analysis, a study had to meet the following criteria: (i) the research was based on a field experiment lasting for more than 3 years, with a known starting year; (ii) experimental treatments were replicated; (iii) experiments had paired treatments of both SI and SR and (iv) cropping systems included at least one growing season for rice, maize or wheat. A total of 68 papers (Table S1 in the Supplement) 
consisting of 70 long-term field experiment sites (Fig. 1) met the criteria for inclusion in our experiment.

Information on soil properties (texture, initial SOC content and bulk density, BD), climate (temperature and precipitation), farming practices (land use, $\mathrm{N}$ fertilization, crop type, crop frequency, $\mathrm{C}$ and nutrient contents of straw, and duration of SI) were also collected. The SOC content or stock and crop yields were obtained directly from tables and/or text of the papers or extracted from the figures using graph digitizing software (GetData Graph Digitizer V2.25; http: //getdata-graph-digitizer.com/, last access: 20 March 2018). For studies in which SOC content was reported with BD, SOC stock ( $\mathrm{Mg} \mathrm{Cha}^{-1}$ ) was calculated using Eq. (1):

SOC stock $=\mathrm{SOC} \times \mathrm{BD} \times H \times 0.1$,

where SOC is SOC content $\left(\mathrm{g} \mathrm{kg}^{-1}\right)$, BD is the soil bulk density $\left(\mathrm{g} \mathrm{cm}^{-3}\right), H$ is the thickness of the soil layer $(0-20 \mathrm{~cm})$ and 0.1 is a constant to adjust the units. The SOC stocks were computed to $20 \mathrm{~cm}$ depth. Soils were mineral soil at $0-20 \mathrm{~cm}$ depth at all sites examined in the 68 papers. In those studies that only reported soil organic matter content, we estimated SOC content as $58 \%$ of the soil organic matter. For the studies in which BD was not available, we estimated the BD for paddy or paddy-upland soil using Eq. (2) (Pan et al., 2003):

$\mathrm{BD}=-0.22 \times \ln (\mathrm{SOC})+1.78$

and for upland soil, the BD was estimated using Eq. (3) (Song et al., 2005):

$\mathrm{BD}=1.377 \times \operatorname{Exp}(-0.0048 \times \mathrm{SOC})$.

For studies that did not report the quantity of incorporated straw $\mathrm{C}$, it was estimated by multiplying the straw $\mathrm{C}$ content (39.9\% for wheat, $44.4 \%$ for maize and $41.8 \%$ for rice; $\mathrm{Na}-$ tional Agro-Tech Extension Center, 1999) by the amount of SI. A sensitivity analysis was conducted to test the robustness of our analysis. We undertook the same meta-analysis process using Eq. (2) for upland and Eq. (3) for paddy, setting a constant $C$ content $(40 \%)$ for all the crop straws (wheat, maize and rice). The results showed that use of different estimation approaches for $\mathrm{BD}$ and straw $\mathrm{C}$ did not have a major impact on the general findings of SOC responses to SI.

To distinguish between the sources of variation for the responses of SOC and crop yield to SI, the paired measurements were further subdivided into subgroups according to the categorical variables listed in Table 1 . Annual fertilizer $\mathrm{N}$ input in the studies ranged from 0 to $720 \mathrm{~kg} \mathrm{~N} \mathrm{ha}^{-1} \mathrm{yr}^{-1}$ and were separated into three levels. The $>400$ and $200-400 \mathrm{~kg}$ $\mathrm{Nha}^{-1} \mathrm{yr}^{-1}$ ranges represent typical farmer fertilizer $\mathrm{N}$ rate and the optimized fertilizer $\mathrm{N}$ rates, respectively, whereas $<200 \mathrm{~kg} \mathrm{Nha}^{-1} \mathrm{yr}^{-1}$ is the low N fertilization level (Ju et al., 2004; X. Zhang et al., 2017). Mean annual precipitation (MAP) and mean annual temperature (MAT) ranged from 117 to $1788 \mathrm{~mm}$ and from 0.9 to $18.4^{\circ} \mathrm{C}$, respectively. The classifications of MAP and MAT in the meta-analysis were based on FAO guidelines for agro-climatic zoning (Fischer et al., 2002). Mainland China was divided into the following four regions according to the geographic location, climate conditions and farming practices: northeast China (NEC), north China (NC), northwest China (NWC) and south China (SC). Detailed information for each region is provided in Table 2. Other categorized variables were crop frequency (number of crops per year, i.e., single, double and triple crops), land-use type (paddy, upland and paddy-upland soils) and straw type (rice, wheat and maize straws).

\subsection{Data analysis}

\subsubsection{Responses of crop yield to straw incorporation (SI)}

The effect size is an index that reflects the magnitude of a treatment's effect (SI) in comparison with a reference treatment (SR) (Borenstein et al., 2009). The effect size of each observation (taken to be the comparison between SI and SR in our study) for crop yield was calculated as the natural $\log$ of the response ratio $(\ln R$; Rosenberg et al., 2000), as in Eq. (4):

$\ln R=\ln \frac{X_{\mathrm{e}}}{X_{\mathrm{c}}}$,

where $X_{\mathrm{e}}$ is the mean crop grain yield of the SI treatment and $X_{\mathrm{c}}$ is the mean grain yield of the control (SR). The relative change in crop yields following SI was also calculated as $(R-1) \times 100 \%$ (Chivenge et al., 2011). Positive values of relative change indicated a promotion effect of SI on crop production and vice versa.

\subsubsection{Responses of SOC to straw incorporation (SI)}

The effect size of SOC was expressed as an annual SOC sequestration rate $\left(\mathrm{Mg} \mathrm{Cha}^{-1} \mathrm{yr}^{-1}\right)$, which was calculated by Eq. (5):

Annual SOC sequestration rate

$$
=\frac{\left(D_{\text {soct }}-D_{\text {soci }}\right)-\left(D_{\text {soct }^{\prime}}-D_{\text {soci }^{\prime}}\right)}{\text { duration }},
$$

where $D_{\text {soct }}$ and $D_{\text {soct' }}$ are SOC stock for the terminal year of experimental SI and SR treatments, respectively; and $D_{\text {soci }}$ and $D_{\text {soci' }}$ are SOC stock for the initial year of SI and SR treatments, respectively. A positive value of annual SOC sequestration rate indicates a SOC stock increase due to SI and a negative difference indicates the opposite effect.

\subsection{Meta-analysis}

A meta-analysis of the random effect model was performed and analyzed using MetaWin 2.1 software (Rosenberg et al., 2000). As standard deviations were rarely available in the 
Table 1. Classification of categorical variables used as explanatory factors.

\begin{tabular}{|c|c|c|c|c|}
\hline Categorical variable & Level 1 & Level 2 & Level 3 & Level 4 \\
\hline Soil texture & clay & loam & silt loam & sandy loam \\
\hline Mean annual temperature $\left(^{\circ}\right)$ & $<10$ & $10-18$ & $>18$ & \\
\hline Mean annual precipitation (mm) & $<600$ & $600-1000$ & $>1000$ & \\
\hline Experimental duration ${ }^{\mathrm{a}}$ (years) & $3-10$ & $11-20$ & $>20$ & \\
\hline Experimental duration ${ }^{\mathrm{b}}$ (years) & $3-5$ & $6-10$ & $11-15$ & $>15$ \\
\hline Straw C $\left(\mathrm{Mg} \mathrm{Cha}^{-1} \mathrm{yr}^{-1}\right)$ & $<1.5$ (Low) & 1.5-3 (Middle) & $>3$ (High) & \\
\hline $\mathrm{N}$ fertilizer $\left(\mathrm{kg} \mathrm{N} \mathrm{ha}^{-1} \mathrm{yr}^{-1}\right)$ & 0-200 (Low) & 200-400 (Middle) & 400-600 (High) & \\
\hline
\end{tabular}

${ }^{a}$ Experiment duration for the response of soil organic carbon to SI. ${ }^{\mathrm{b}}$ Experiment duration for the response of crop yield to SI.

Table 2. Basic information on agricultural regions in the current analysis.

\begin{tabular}{|c|c|c|c|c|c|c|}
\hline Region & Province & $\begin{array}{l}\text { Crop frequency } \\
\left(\text { season } \mathrm{yr}^{-1} \text { ) }\right.\end{array}$ & $\begin{array}{l}\text { Major } \\
\text { crop }\end{array}$ & $\begin{array}{l}\text { MAP } \\
(\mathrm{mm})\end{array}$ & $\begin{array}{r}\text { MAT } \\
\left({ }^{\circ}\right)\end{array}$ & $\begin{array}{l}\text { Soil } \\
\text { texture }\end{array}$ \\
\hline NEC & Heilongjiang, Jilin, Liaoning & single & $\begin{array}{l}\text { maize, } \\
\text { soybean, wheat }\end{array}$ & $450-716$ & $0-8.1$ & $\begin{array}{l}\text { clay, loam, } \\
\text { silt loam }\end{array}$ \\
\hline $\mathrm{NC}$ & $\begin{array}{l}\text { Beijing, Hebei, Henan, } \\
\text { Shandong, Shanxi, Anhui } \\
\text { (north region) }\end{array}$ & double & maize, wheat & $455-821$ & $7.3-14.8$ & $\begin{array}{l}\text { clay, loam, } \\
\text { sandy loam }\end{array}$ \\
\hline NWC & $\begin{array}{l}\text { Shanxi, Gansu, } \\
\text { Qinghai, Xinjiang }\end{array}$ & single/double & maize, wheat & $117-632$ & $5.7-13.0$ & $\begin{array}{l}\text { clay, loam, } \\
\text { silt loam }\end{array}$ \\
\hline $\mathrm{SC}$ & $\begin{array}{l}\text { Jiangsu, Anhui (central and } \\
\text { south region), Hubei, Hunan, } \\
\text { Zhejiang, Shanghai, Guangxi, } \\
\text { Chongqing, Sichuan, } \\
\text { Jiangxi, Fujian }\end{array}$ & double/triple & $\begin{array}{l}\text { maize, wheat, } \\
\text { rice, rapeseed }\end{array}$ & $1038-1795$ & $14.8-19.5$ & $\begin{array}{l}\text { clay, loam, } \\
\text { silt loam, } \\
\text { sandy loam }\end{array}$ \\
\hline
\end{tabular}

NEC: northeast China; NC: north China; NWC: northwest China; SC: south China. MAP: mean annual precipitation (mm); MAT: mean annual temperature ( $\left.{ }^{\circ} \mathrm{C}\right)$.

selected literature, an unweighted analysis was adopted to include as many studies as possible (Hedges et al., 1999; Rosenberg et al., 2000). We used bootstrapping (4999 iterations) to generate the mean effect size and bias-corrected $95 \%$ confidence interval $(95 \% \mathrm{CI})$ for each categorical variable. Mean effect sizes were considered to be significantly different if their $95 \%$ CIs did not overlap, and were considered to be significantly different from the control if their $95 \%$ CIs did not overlap with zero (Chivenge et al., 2011). We accepted the mean effect sizes of the categories to be significantly different between the levels of the factors if the $P$ values of the between-group heterogeneity $\left(Q_{\mathrm{b}}\right)$ were less than the 0.05 level $(P<0.05)$.

\subsection{Regression analysis}

A stepwise regression analysis was applied to analyze the relationship between SOC contents, the input rate of total nutrients $\left(\mathrm{N}, \mathrm{P}_{2} \mathrm{O}_{5}\right.$ and $\left.\mathrm{K}_{2} \mathrm{O}\right)$ and crop yields. Regression analysis was also used to examine the SOC responses to experimental factors (i.e., straw $\mathrm{C}$ input rate, experiment duration and initial SOC content). The relationship between yield response to
SI and control yield was also examined. All regression analyses were performed using SPSS version 20.0 (SPSS Inc., Chicago, USA), and the results were considered statistically significant if $P<0.05$.

\section{Results}

\subsection{SOC and crop yield}

For all the experiments studied, a significant positive linear regression was determined between SOC content and crop yield (Fig. $2 ; R^{2}=0.42, P<0.001$ ). If the fertilization variables were considered, a significant linear relationship between crop yield and SOC content was revealed, i.e., Yield $\left(\mathrm{Mg} \mathrm{ha}^{-1} \mathrm{yr}^{-1}\right)=0.933+0.267 \times \mathrm{SOC}$ $\left(\mathrm{g} \mathrm{kg}^{-1}\right)+0.008 \times N \quad\left(\mathrm{~kg} \mathrm{ha}^{-1} \mathrm{yr}^{-1}\right)+0.010 \times \mathrm{K}_{2} \mathrm{O}$ $\left(\mathrm{kg} \mathrm{ha}^{-1} \mathrm{yr}^{-1}\right)\left(R^{2}=0.69, P<0.01, n=100\right)$, in which the variable of fertilizer $\mathrm{P}_{2} \mathrm{O}_{5}$ was excluded by using the method of stepwise regression analysis. These results indicated that SOC content explained $42 \%$ of the yield variations while SOC content and fertilizer input altogether 


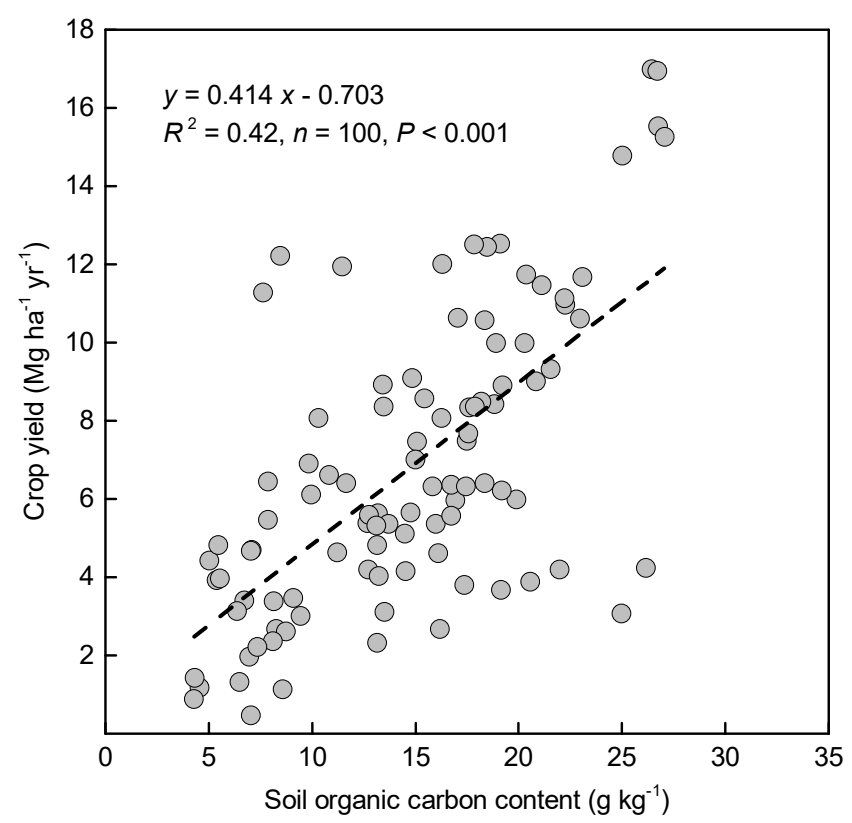

Figure 2. Relationship between crop yield and soil organic carbon content.

explained $69 \%$. Overall, an increase of $1 \mathrm{~g} \mathrm{~kg}^{-1} \mathrm{SOC}$ content could improve crop yield by $267-414 \mathrm{~kg} \mathrm{ha}^{-1} \mathrm{yr}^{-1}$, or $101-157 \mathrm{~kg} \mathrm{ha}^{-1} \mathrm{yr}^{-1}$ of yield increase if converted to $1 \mathrm{Mg} \mathrm{Cha}^{-1} \mathrm{yr}^{-1}$ of SOC stock increase $(20 \mathrm{~cm}$ depth, with soil BD assumed to be $1.32 \mathrm{~g} \mathrm{~cm}^{-3}$; Han et al., 2012).

\subsection{Responses of crop yield to straw incorporation (SI)}

Overall, SI significantly increased annual crop yield by $13.4 \%$ (95\% CI, 9.3-18.4\%) relative to SR in China's cropland (Fig. 3a). The yield responses to SI were, however, different among the four regions of China (Fig. 3b). The greatest yield increment corresponding to SI was observed in NEC (mean $26.8 \%, 95 \%$ CI, 18.1-38.2\%), compared with SC $(11.6,7.3-17.7 \%)$ and $\mathrm{NC}(9.8,3-26.7 \%)$, and the poorest response was found in NWC $(7.3,1.8-13.6 \%)$. Yield increase was positively related to the duration of SI for the first 15 years. It then increased from $4.9 \%(3.0-7.5 \%)$ after $3-5$ years, to $12.3 \%(5.1-20.7 \%)$ after $6-10$ years, and to $18.6 \%(12.4-26.5 \%)$ after $11-15$ years. After 15 years, the yield increase $(12.6 \%, 5.1-20.4 \%)$ tended to decline to a level similar to that reported for 6-10 years (Fig. 3d). Grain yield responses to SI were greater in single and double cropping systems than in the triple cropping system (Fig. 3c), but there were no significant differences between single and double cropping systems (Fig. 3c).

The effect of SI on crop yield varied among crops, i.e., $8.7 \%$ (4.1-13.5\%), $20.8 \%$ (12.8-31.0\%) and $10.4 \%$ (6.6$15.3 \%$ ) yield increase for wheat, maize and rice, respectively (Fig. 4). Yield increase above the control (SR) was greater

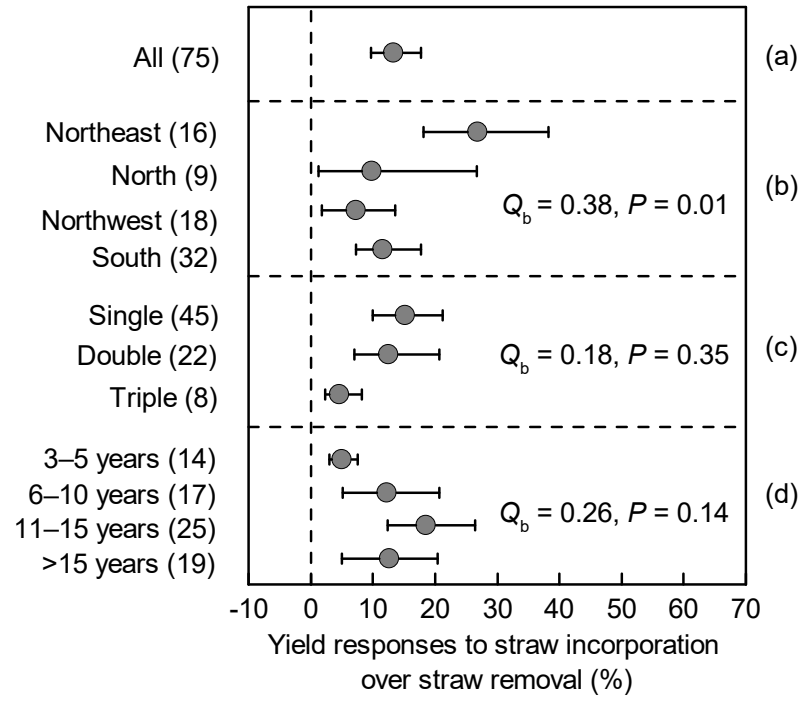

Figure 3. Responses of crop yield to SI compared with SR (a), categorized into (b) region, (c) crop frequency and (d) experiment duration. Yield responses are expressed as the relative increase (\%) compared with control (SR) with $95 \%$ CIs represented by the error bars. Numbers of paired observations are in parentheses. Between-group heterogeneity $\left(Q_{\mathrm{b}}\right)$ and the probability $(P)$ were used to describe statistical differences in yield responses between different levels of the categorized factors.

when the control yield was low, and as the control yield increased the yield responses to SI became smaller (Fig. 4).

Crop yield responses increased with the amount of SI, and the greatest response $(28.4 \%, 18.6-40.9 \%)$ was observed at the high level of straw input (>3 Mg Cha ${ }^{-1} \mathrm{yr}^{-1}$; Table 3 ). Crop yield responses generally increased in response to the combination of straw application with mineral $\mathrm{N}$ application, i.e., increasing from $11.5 \%(6.2-18.0 \%)$ to $18.4 \%$ (11.9$27.6 \%$ ) when the $\mathrm{N}$-application rate increased from 0-200 to $200-400 \mathrm{~kg} \mathrm{~N} \mathrm{ha}^{-1} \mathrm{yr}^{-1}$. However, the highest level of $\mathrm{N}$ fertilizer $\left(>400 \mathrm{~kg} \mathrm{Nha}^{-1} \mathrm{yr}^{-1}\right)$ did not result in a significant additional yield increase $(18.8 \%, 1.6-54.2 \% ; P>0.05)$ relative to $200-400 \mathrm{~kg} \mathrm{ha}^{-1} \mathrm{yr}^{-1}$ (Table 3).

\subsection{Responses of SOC to straw incorporation (SI)}

Annual SOC sequestration in response to SI was enhanced with an average rate of 0.35 (95\% CI, 0.31-0.40) $\mathrm{Mg}$ $\mathrm{Cha}^{-1} \mathrm{yr}^{-1}$ in the experiments reviewed (Fig. 5a). A significant effect of $Q_{\mathrm{b}}$ was found for the categories of geographical regions, SI duration, crop frequency and soil texture (Fig. 5b, c, e, i; $P<0.05$ ), but not for landuse type, straw type, MAT or MAP (Fig. 5d, f, g, h; $P>0.05)$. Compared with the SR treatments, the greatest SOC sequestration rates were recorded in NEC $(0.57$, $\left.0.41-0.77 \mathrm{Mg} \mathrm{Cha}^{-1} \mathrm{yr}^{-1}\right)$, followed by SC $(0.36,0.30-$ $\left.0.43 \mathrm{Mg} \mathrm{Cha}^{-1} \mathrm{yr}^{-1}\right), \mathrm{NC}\left(0.33,0.25-0.40 \mathrm{Mg} \mathrm{Cha}^{-1} \mathrm{yr}^{-1}\right)$ 


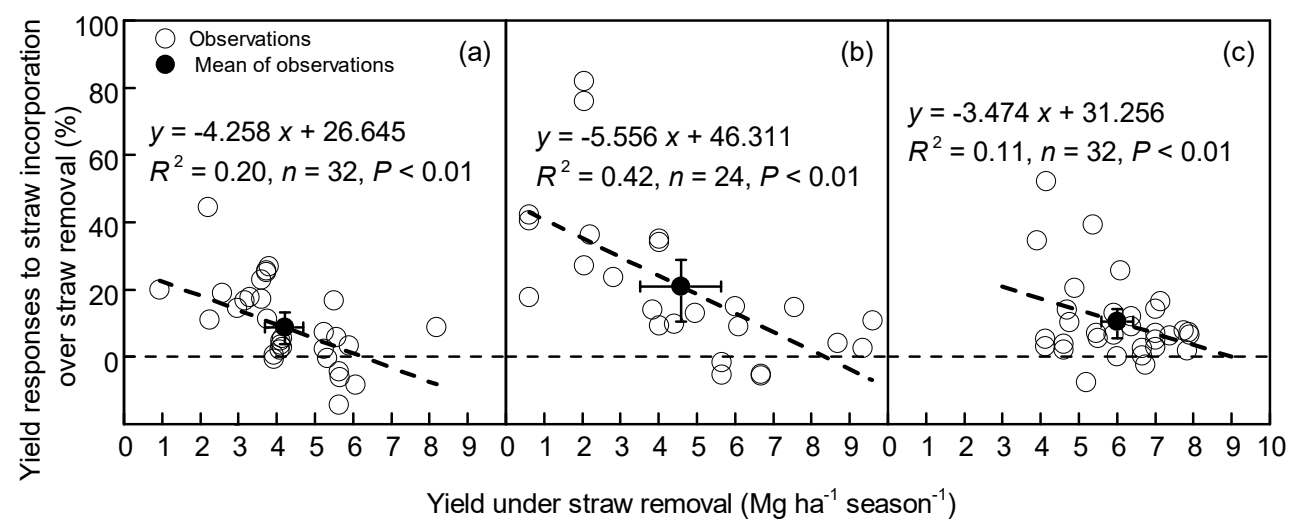

Figure 4. Relationships between crop yield responses to SI and control yield under SR for (a) wheat, (b) maize and (c) rice. Yield responses are expressed as the relative increase (\%) compared with the control (SR). Error bars in horizontal and vertical directions represent $95 \%$ CIs of the control yield and yield responses, respectively.

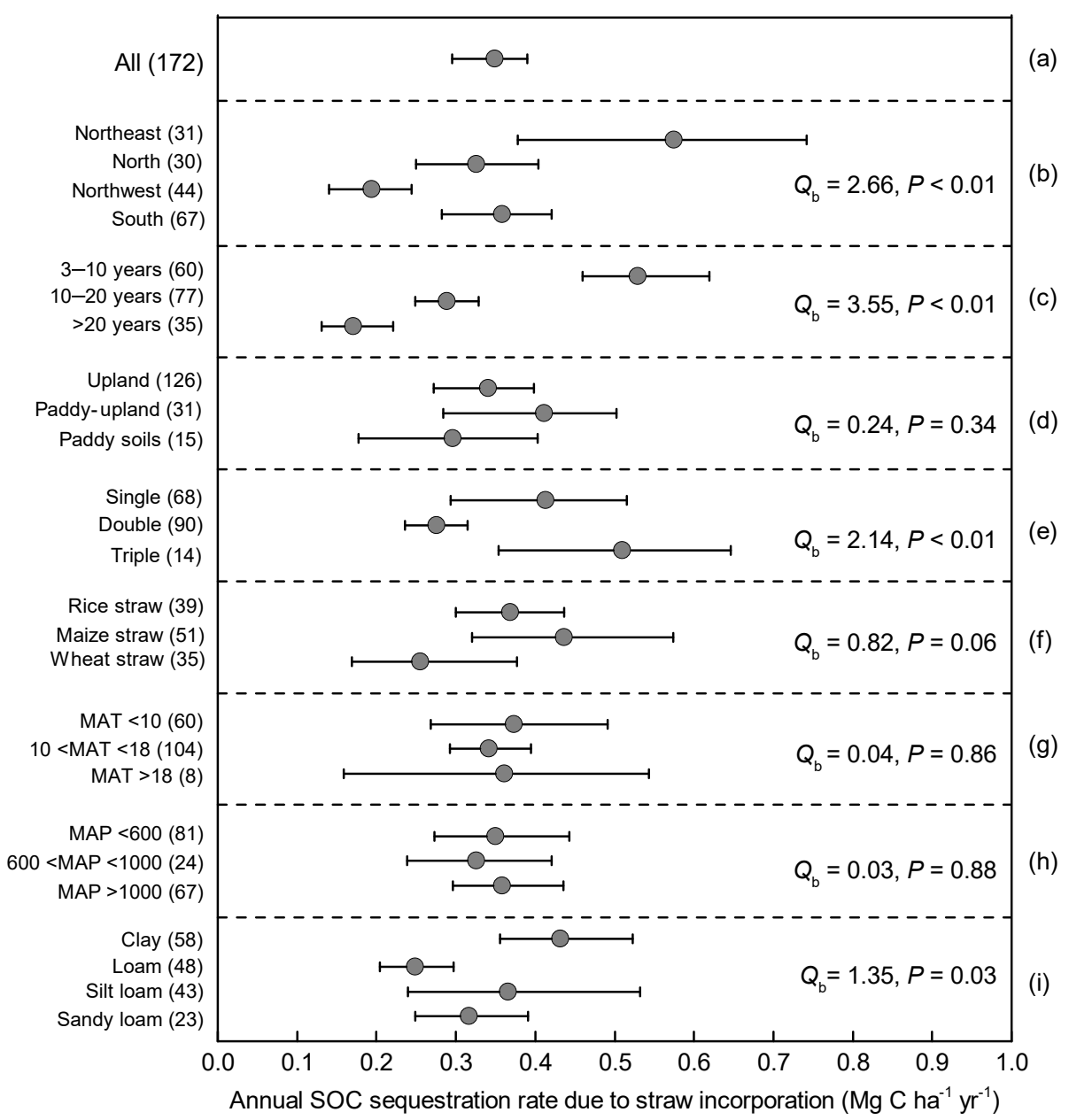

Figure 5. Responses of soil organic carbon (SOC) to SI compared with SR (a) categorized into (b) region, (c) experiment duration, (d) land use, (e) crop frequency (season $\mathrm{yr}^{-1}$ ), (f) straw type, (g) mean annual temperature (MAT), (h) mean annual precipitation (MAP) and (i) soil texture. The SOC responses are expressed as the average annual SOC sequestration rate $\left(\mathrm{Mg} \mathrm{Cha}^{-1} \mathrm{yr}^{-1}\right)$ with $95 \%$ CIs represented by the error bars. Numbers of paired observations are in parentheses. Between-group heterogeneity $\left(Q_{\mathrm{b}}\right)$ and the probability $(P)$ were used to describe statistical differences of SOC responses between different levels of the categorized factors. 


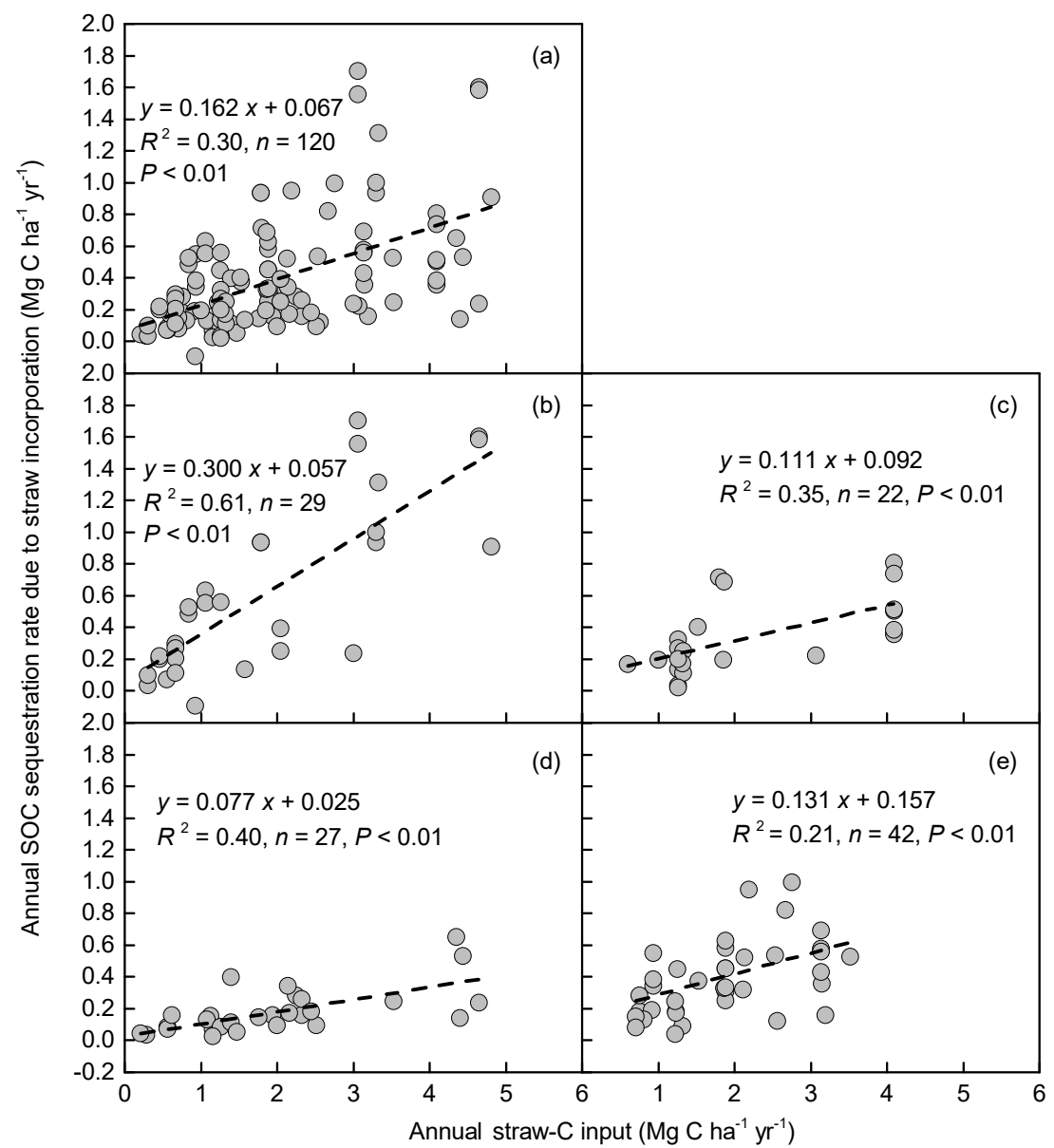

Figure 6. Relationships between annual soil organic carbon (SOC) sequestration rate and straw carbon input for (a) national scale, (b) northeast China, (c) north China, (d) northwest China and (e) south China.

and NWC (0.19, 0.14-0.25 Mg Cha $\mathrm{Cr}^{-1}$ ) (Fig. 5b). The annual SOC sequestration rates were significantly $(P<0.05)$ greater in the shortest time interval $(3-10$ years $)$ after SI began $\left(0.53,0.44-0.63 \mathrm{Mg} \mathrm{Cha}^{-1} \mathrm{yr}^{-1}\right)$, compared with the medium term (10-20 years; $0.29,0.23-0.37 \mathrm{Mg}$ $\mathrm{Cha}^{-1} \mathrm{yr}^{-1}$ ) or long term (> 20 years; $0.17,0.13-0.21 \mathrm{Mg}$ $\mathrm{Cha}^{-1} \mathrm{yr}^{-1}$ ) (Fig. 5c). The effect of SI on SOC sequestration varied between different crop frequencies in the order: triple $\left(0.51,0.37-0.67 \mathrm{Mg} \mathrm{Cha}^{-1} \mathrm{yr}^{-1}\right)>$ single $(0.41$, $\left.0.31-0.53 \mathrm{Mg} \mathrm{Cha}{ }^{-1} \mathrm{yr}^{-1}\right)>$ double $(0.28,0.24-0.32 \mathrm{Mg}$ $\left.\mathrm{Cha}^{-1} \mathrm{yr}^{-1}\right)$. The SOC sequestration after SI in clay soils was significantly $(P<0.05)$ higher than loam soil but was not significantly different to silt loam or sandy loam soils (Fig. 5i; $P>0.05$ ). Rice straw and maize straw tended to sequester more SOC than wheat straw, but the difference was not statistically significant (Fig. 5f; $P>0.05$ ).

The mean SOC sequestration rate was $0.20(0.16-$ $0.25) \mathrm{Mg} \mathrm{Cha}^{-1} \mathrm{yr}^{-1}$ under the lowest straw $\mathrm{C}$ input level $\left(<1.5 \mathrm{Mg} \mathrm{Cha}{ }^{-1} \mathrm{yr}^{-1}\right)$ but increased significantly to 0.70 (0.53-0.88) $\mathrm{Mg} \mathrm{Cha}^{-1} \mathrm{yr}^{-1}$ under the highest straw $\mathrm{C}$ in- put $\left(>3 \mathrm{Mg} \mathrm{Cha}^{-1} \mathrm{yr}^{-1}\right)($ Table $3 ; P<0.05)$. The $\mathrm{N}$ fertilizer input rate significantly increased the SOC responses to SI $(P<0.01)$. For example, the average annual SOC sequestration rate increased from $0.27(0.22-0.32)$ to $0.69(0.53-$ $0.81) \mathrm{Mg} \mathrm{Cha}^{-1} \mathrm{yr}^{-1}$ when the $\mathrm{N}$ application rates increased from 0-200 to $>400 \mathrm{~kg} \mathrm{~N} \mathrm{ha}^{-1} \mathrm{yr}^{-1}$. Interestingly, we found that there was a significant positive interaction of SI with $\mathrm{N}$ fertilizer input on SOC accumulation (Table 3; $P<0.05$ ).

\subsection{Relationships between SOC sequestered and straw input or experiment duration}

The meta-analysis revealed significant positive linear relationships between annual SOC sequestration rate and straw C input across China (Fig. 6; $P<0.01$ ). Based on the straw $\mathrm{C}$ conversion efficiency derived from the regression equations (slope of the linear correlation equation; Kong et al., 2005), the conversion efficiency of straw $\mathrm{C}$ to SOC was $16 \% \pm 2 \%$ (mean \pm standard error) for the whole of China and $30 \% \pm 4 \%$ in NEC, $11 \% \pm 3 \%$ in NC, $8 \% \pm 2 \%$ in NWC and $13 \% \pm 4 \%$ in SC (Fig. 6). 


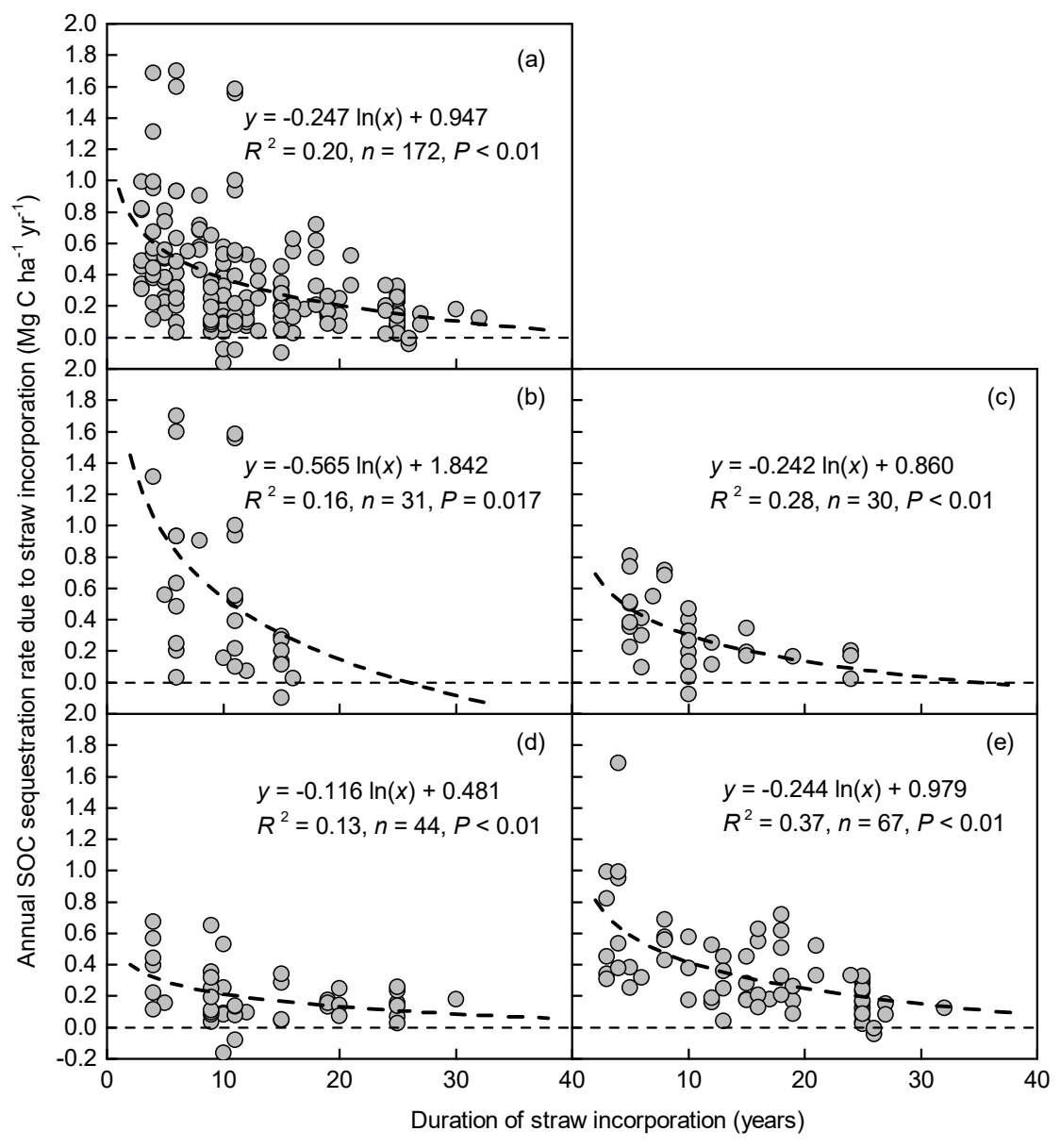

Figure 7. Relationships between annual soil organic carbon (SOC) sequestration rate and SI duration for (a) national scale, (b) northeast China, (c) north China, (d) northwest China and (e) south China.

There was a significant logarithmic relationship between annual SOC sequestration rate and SI duration (Fig. 7; $P<0.05)$. A rapid decline in SOC sequestration rate was observed after the initial stage of SI, especially in NEC and SC, and then the SOC sequestration rate decreased to a steady state. The SOC increment diminished to negligible after 46, 26, 35, 63 and 55 years of SI in the whole of China, NEC, NC, NWC and SC, respectively (Fig. 7).

\section{Discussion}

The results of the meta-analysis suggest that SI increases SOC stocks and crop yields in experimental trials across China, regardless of the climate or land use. The SOC gains were significant in the short term, but the largest crop yield response was observed up to 15 years after SI began. This conclusion is based on a wide range of soils and climate conditions and suggests that farmers across the world may use this simple management tool to increase their outputs by improving the quality of their soil, while mitigating climate change.

\subsection{Increase in SOC by straw incorporation (SI)}

The incorporation of straw unsurprisingly enhanced SOC stocks in China's cropland at an average rate of $0.35 \mathrm{Mg}$ $\mathrm{Cha}^{-1} \mathrm{yr}^{-1}$. This confirms the findings of previous metaanalyses of significant positive SOC responses to straw input (Lu et al., 2009; Lehtinen et al., 2014; Liu et al., 2014). Our result is comparable to the SOC sequestration rates of 0.1$0.3 \mathrm{Mg} \mathrm{C} \mathrm{ha}^{-1} \mathrm{yr}^{-1}$ in the croplands of the United States (Watson et al., 2000) and the global estimates of $0.3 \mathrm{Mg}$ $\mathrm{Cha}^{-1} \mathrm{yr}^{-1}$ (IPCC, 2000) but only half of the estimation for the EU (0.7 Mg Cha ${ }^{-1} \mathrm{yr}^{-1}$; Smith, 2004). SI provides a direct $\mathrm{C}$ source for the formation of SOC (Mulumba and Lal, 2008; Blanco-Canqui and Lal, 2009), and the greater the annual straw $\mathrm{C}$ input rate, the faster SOC sequestration increased (Table 3, Fig. 6). Significant linear relationships between SOC responses and organic $\mathrm{C}$ input were also reported in previous meta-analyses (Liu et al., 2014; Maillard and 


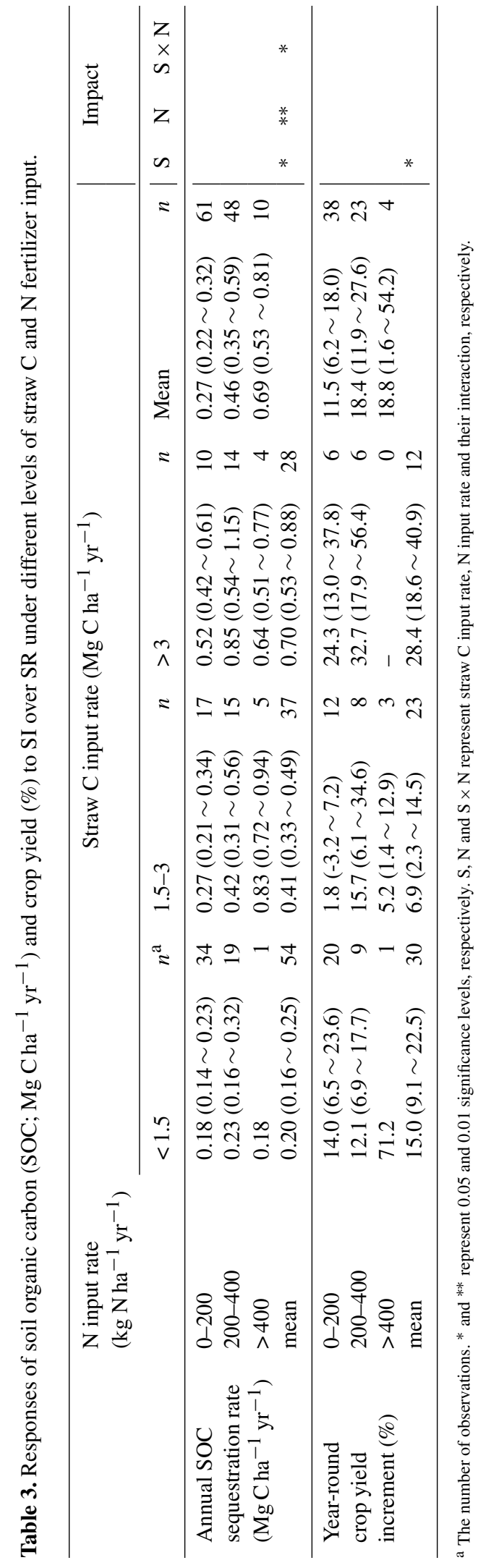

Angers, 2014). Similarly, high crop frequency, which was accompanied by a large amount of above-ground crop residues, resulted in greater SOC sequestration (Fig. 5e; $P<0.05$ ), supporting the findings of Luo et al. (2010).

Addition of $\mathrm{N}$ fertilization enhanced the effect of SI (Table 3), presumably because straw has a high $\mathrm{C}: \mathrm{N}$ ratio and much of the $\mathrm{N}$ added at lower rates (up to $400 \mathrm{~kg} \mathrm{ha}^{-1}$ ) was immobilized when straw input was high $\left(>3 \mathrm{Mg} \mathrm{Cha}^{-1}\right)$, at least in the short term (Singh et al., 1992). Furthermore, $\mathrm{N}$ fertilizer addition can enhance both above- and belowground biomass production (Kuzyakov and Domanski, 2000; Neff et al., 2002; Ladha et al., 2011), leading to a greater SOC sequestration when the crop-derived $\mathrm{C}$ is incorporated (Gong et al., 2012). The effect of soil texture on SOC responses to SI was significant (Fig. 5i; $P<0.05$ ); clay soils have a propensity to stabilize SOC by providing chemical and physical protection (Six et al., 2002), which supported the high sequestration rates in clay soils in the current study (Fig. 5i).

In NEC, where the initial SOC stocks are very high (Yu et al., 2012), a rapid decline of SOC stocks has been experienced since the 1970s (from 48.7 in the 1980 s to $42.4 \mathrm{Mg}$ $\mathrm{Cha}^{-1}$ in 2006; Pan et al., 2010), due to the large-scale land reclamation of wetland to cropland (Gao et al., 2015) and long-term low $\mathrm{C}$ input (Yu et al., 2012). At the same time, however, SOC stocks increased in the majority of croplands in other regions of China (Yu et al., 2012). In this context, a significant spatial variation in SOC responses to SI was observed (Fig. $5 \mathrm{~b} ; P<0.05$ ): $30 \%$ of the added $1 \mathrm{Mg}$ $\mathrm{C} \mathrm{ha}^{-1} \mathrm{yr}^{-1}$ straw $\mathrm{C}$ was sequestrated as SOC in NEC, compared with $8-13 \%$ in other regions (Fig. 6). Additionally, the lower temperature (mean annual temperature of $0.9-8.1^{\circ} \mathrm{C}$; Table S1) in NEC could also restrict SOC decomposition (Karhu et al., 2014) and favor the SOC accumulation. This supports the meta-analysis conducted by Tian et al. (2015), which also reported a greater SOC increment in northeast China from manure application compared with other regions. However, according to a farmer survey across China carried out by G. Zhang et al. (2017), the percentage of SI by farmers was only $8.7 \%$ in NEC, while $32.7 \%$ of farmers burnt the straws in the field. Hence, there is an urgent need to encourage the local farmers to recycle the crop straw in NEC.

The impacts of land-use type on straw-induced SOC sequestration were not statistically significant (Fig. 5d; $P>0.05$ ), in agreement with the previous meta-analysis of Liu et al. (2014). This may be because alternative wetting and drying has been widely applied as a common practice to improve crop yield in paddy soils in China (Zhao et al., 2013). This practice would stimulate microbial activity and increase organic matter mineralization during the mid-season drainage period (Mikha et al., 2005), thus leading to a less stable form of SOC in paddy soils (Cui et al., 2012). As arable cropping systems are complex ecosystems controlled by both natural factors and farming practices (Lohila et al., 2003; Song et al., 2005), the direct effect of MAT and MAP 
on SOC responses to SI might be dominated by farming practices (Fig. 5g, h; $P>0.05$ ). Previous meta-analyses (Luo et al., 2010; Liu et al., 2014; Maillard and Angers, 2014) also reported similar results. Our results imply that improvement of SOC through SI might also be applicable to other regions in the world with different climate conditions or land uses.

Similar to Tian et al. (2015), we observed that the SOC stocks increased regardless of the initial SOC contents (data not shown). Moreover, a rapid SOC increase occurred in the first two decades rather than in later periods (26-63 years) of SI (Figs. 5c, 7), which suggests that an equilibrium between $\mathrm{C}$ input and decomposition might occur at the decadal scale (West and Six, 2007). This supports the need for continued investment in long-term field experiments to provide robust support for policy development (MacDonald et al., 2015).

\subsection{Increase in crop yield by straw incorporation (SI)}

SI significantly increased the overall crop yield by $13.4 \%$ compared with SR. This yield increase is similar in magnitude to a recent meta-analysis of global data (12\%; Liu et al., 2014), but larger than other observations from China (up to $9 \%$ increase; Huang et al., 2013; Zhao et al., 2015; Wang et al., 2015; Xu et al., 2017) and the EU (6\% increase; Lehtinen et al., 2014). The lower estimates reported in previous studies focused on more limited geographical zones, i.e., most studies in Lehtinen et al. (2014) were in the Mediterranean region, only NC was considered by Xu et al. (2017) and only three sites from NEC were analyzed by Wang et al. (2015) and Huang et al. (2013). Shorter study durations, e.g., 8-12 years in Zhao et al. (2015), might lead to a relatively low yield response, whereas our analysis shows that the greatest benefits of SI on crop yield were achieved after 11-15 years of SI (Fig. 3d). According to the current cereal production in China (616 million $\mathrm{Mg}$; National $\mathrm{Bu}-$ reau of Statistics of China, 2016), this straw-induced yield increment $(13.4 \%)$ results in an additional 82.6 million $\mathrm{Mg}$ of agricultural products, which could feed 0.2 billion people or $15 \%$ of China's population at the current per-capita food consumption of $388 \mathrm{~kg} \mathrm{yr}^{-1}$ (Central People's GovernmentPRC, 2008).

As previous meta-analyses (Liu et al., 2014; Wang et al., 2015) and the current study revealed, SI significantly increases SOC, which is a key determinant in crop production (Singh et al., 2002). Each increase of $1 \mathrm{Mg} \mathrm{Cha}{ }^{-1}$ SOC in the root zone could improve crop yield by 30 $300 \mathrm{~kg} \mathrm{ha}^{-1} \mathrm{yr}^{-1}$ in Asia (Lal, 2013). This is supported by our finding that $101-157 \mathrm{~kg} \mathrm{ha}^{-1} \mathrm{yr}^{-1}$ of crop yield increase could be achieved (Fig. 2). Straw contains various macroand micro-nutrients, which can contribute to the nutrient budget of farms if returned to the soil (Lal, 2013). In the current study, the average annual $\mathrm{N}, \mathrm{P}$ and $\mathrm{K}$ nutrients derived from straw residues were $35 \mathrm{~kg} \mathrm{~N}, 13 \mathrm{~kg} \mathrm{P}_{2} \mathrm{O}_{5}$ and $78 \mathrm{~kg}$ $\mathrm{K}_{2} \mathrm{Oha}^{-1} \mathrm{yr}^{-1}$, which accounted for ca. 15,11 and $52 \%$ of the average annual mineral $\mathrm{N}, \mathrm{P}$ and $\mathrm{K}$ input, respectively.
Similarly, Wang et al. (2015) reported a similar annual straw $\mathrm{N}$ input (39.6 $\mathrm{kg} \mathrm{N} \mathrm{ha}^{-1} \mathrm{yr}^{-1}$ ) and beneficial yield response. Singh et al. (2002) also suggested that crop residue recycling affects crop production substantially by maintaining the soil $\mathrm{K}$ balance. For the response to SI, the maize crop achieved a higher yield increase than wheat or rice crops (Fig. 4), which agrees with the study of Hijbeek et al. (2017). This may be because maize grows under higher temperature and precipitation (Tan et al., 2017), and these conditions favor faster straw decomposition and result in a rapid and complete nutrient release (Ladha et al., 2011; Hartmann et al., 2014).

SI also reduces soil compaction (Soane, 1990), moderates soil temperature (Blanco-Canqui and Lal, 2009), retains soil water in the plow layer (Zhang et al., 2014) and immobilizes $\mathrm{N}$ for later release in the growing season (Hansen et al., 2015), all of which may promote crop production. In the triple cropping areas of China, promising climate conditions (MAP > $1000 \mathrm{~mm}$, MAT: $14.8-17.6^{\circ} \mathrm{C}$; Table S1) ensured a high land productivity, e.g., averaged $13.5 \mathrm{Mg} \mathrm{ha}^{-1} \mathrm{yr}^{-1}$ of crop yield in our study. The low water availability and large temperature fluctuations in the single cropping regions are likely to be limiting factors for crop yield (MAP: 117-716 mm, MAT: $0.9-11.5{ }^{\circ} \mathrm{C}$; Table S1). Hence, strawinduced soil water retention and temperature moderation might contribute to better crop production in the single cropping system compared with that in the triple cropping system. The $\mathrm{N}$ immobilization of SI has potential environmental benefits, e.g., reduced losses by leaching and $\mathrm{N}_{2} \mathrm{O}$ emissions (Meng et al., 2016) and improved $\mathrm{N}$ use efficiency (Yao et al., 2017). In our meta-analysis, under the fertilizer $\mathrm{N}$ levels of 200-400 and $>400 \mathrm{~kg} \mathrm{~N} \mathrm{ha}^{-1} \mathrm{yr}^{-1}$, which have been widely adopted in cropland in China (Ju et al., 2004), a $18 \%$ of yield increase due to SI was observed compared with SR (Table 3). This highlighted that SI is an effective measure for both improving crop yield and decreasing the risk of $\mathrm{N}$ leaching in intensive agricultural regions.

Our study found that yield responses tended to increase with time only when SI duration was $<15$ years (Fig. 3d). This response indicates that long-term SI is necessary to achieve a high soil fertility and continuous yield sustainability (Bi et al., 2009). Indeed, the yield increase was relatively low in the initial stage (5\% in the first 3-5 years; Fig. 3d) but increased thereafter. However, unlike several other studies (Wang et al., 2015; Zhao et al., 2015), we observed that the yield increase tended to decline after a 15-year timespan of SI (Fig. 3d), implying a potential saturation effect of SI on soil fertility. We also found that crop yield response to SI was greater when the control yield was low (Fig. 4), which highlights the importance of straw management in low-productivity regions (Chivenge et al., 2011).

\subsection{Uncertainties in our study}

Although meta-analysis is an effective statistical approach, our conclusions might be constrained by several uncertain- 
ties. Soil BD and straw $\mathrm{C}$ input data were unavailable in some papers, which was resolved through estimation using empirical functions, although our sensitivity analyses found the errors due to these estimations were acceptable. For some categories, e.g., MAT and $\mathrm{N}$ fertilizer input, the available dataset was small $(n<10)$ if divided into subgroups, which might hamper the estimation for SI effect under these subgroups. In addition, the lack of information on the SI methods (chopped or not) and tillage (non-tillage or tillage) might increase the deviation of SI in different natural contexts and using farming practices. Hence, further field experimental studies are needed to examine the effects of straw management in more detail.

\section{Conclusions}

Our study found that SI significantly sequestered SOC at the rate of $0.35 \mathrm{Mg} \mathrm{Cha}^{-1} \mathrm{yr}^{-1}$, increased crop yield by $13.4 \%$ and had a SOC conversion efficiency of $16 \%$ across the whole of China. A coupled benefit of SI at $3 \mathrm{MgCha}^{-1} \mathrm{yr}^{-1}$ with the mineral $\mathrm{N}$ rate of $200-400 \mathrm{~kg} \mathrm{~N} \mathrm{ha}^{-1} \mathrm{yr}^{-1}$ was found to be the best combination for farmer use, with crop yield increases of $32.7 \%$ and SOC sequestrated by the rate of $0.85 \mathrm{Mg} \mathrm{Cha}^{-1} \mathrm{yr}^{-1}$. Soil texture and crop frequency were also recognized as the two factors significantly influencing the SI effects on SOC. The NEC region was identified as the region with greatest potential to simultaneously realize the SI benefit on SOC sequestration and yield improvement. As SI progressed, a rapid SOC increase occurred in the first two decades, and the crop yield increase peaked at around 15 years. Our study confirmed the multiple beneficial effects of SI in sustainable intensive agriculture in China, which may also be applicable to other regions of the world.

Data availability. Data are available by direct request to the corresponding author.

\section{The Supplement related to this article is available online at https://doi.org/10.5194/bg-15-1933-2018-supplement.}

Author contributions. $\mathrm{XH}$ and $\mathrm{CX}$ contributed equally to this work. FM, XH and CX conceived and designed the study. XH, CX and $\mathrm{XW}$ carried the data collection and analysis. $\mathrm{XH}$ and $\mathrm{CX}$ wrote the original draft. JAJD, RB, FM and WW reviewed and revised the draft.

Competing interests. The authors declare that they have no conflict of interest.
Disclaimer. Funders had no role in conceiving the study, collecting or analyzing data, or manuscript preparation.

Acknowledgements. This study was financially supported by the National Key Research and Development Program of China (grant no. 2016YFD0800100). This work was supported as part of Rothamsted Research's Institute Strategic Programme - Soil to Nutrition (BB/PO1268X/1), funded by the UK Biotechnology and Biological Sciences Research Council. We thank the anonymous referees for their helpful comments and suggestions that greatly improved the manuscript.

Edited by: Yakov Kuzyakov

Reviewed by: two anonymous referees

\section{References}

Amundson, R., Berhe, A. A., Hopmans, J. W., Olson, C., Sztein, A. E., and Sparks, D. L.: Soil and human security in the 21st century, Science, 348, 1-6, https://doi.org/10.1126/science.1261071, 2015.

Bai, Z. G., Dent, D. L., Olsson, L., and Schaepman, M. E.: Proxy global assessment of land degradation, Soil Use Manage., 24, 223-234, https://doi.org/10.1111/j.1475-2743.2008.00169.x, 2008.

Bi, L. D., Zhang, B., Liu, G. R., Li, Z. Z., Liu, Y. R., Ye, C., Yu, X. C., Lai, T., Zhang, J. G., Yin, J. M., and Liang, Y.: Long-term effects of organic amendments on the rice yields for double rice cropping systems in subtropical China, Agr. Ecosyst. Environ., 129, 534-541, https://doi.org/10.1016/j.agee.2008.11.007, 2009.

Bindraban, P. S., van der Velde, M., Ye, L. M., van den Berg, M., Materechera, S., Kiba, D. I., Tamene, L., Ragnarsdottir, K. V., Jongschaap, R., Hoogmoed, M., Hoogmoed, W., van Beek, C., and van Lynden, G.: Assessing the impact of soil degradation on food production, Curr. Opin. Env. Sust., 4, 478-488, https://doi.org/10.1016/j.cosust.2012.09.015, 2012.

Blanco-Canqui, H. and Lal, R.: Crop residue management and soil carbon dynamics, in: Soil Carbon Sequestration and the Greenhouse Effect, 2nd Edn., edited by: Lal, R. and Follett, R. F., Soil Science Society of America, Madison, USA, 291-309, 2009.

Bolinder, M. A., Andren, O., Katterer, T., de Jong, R., VandenBygaart, A. J., Angers, D. A., Parent, L. E., and Gregorich, E. G.: Soil carbon dynamics in Canadian Agricultural Ecoregions: Quantifying climatic influence on soil biological activity, Agr. Ecosyst. Environ., 122, 461-470, https://doi.org/10.1016/j.agee.2007.03.001, 2007.

Borenstein, M., Hedges, L. V., Higgins, J. P. T., and Rothsein, H. R.: Introduction to Meta-Analysis, 1st Edn., John Wiley \& Sons, Ltd, 2009.

Cai, Z. C. and Qin, S. W.: Dynamics of crop yields and soil organic carbon in a long-term fertilization experiment in the Huang-Huai-Hai Plain of China, Geoderma, 136, 708-715, https://doi.org/10.1016/j.geoderma.2006.05.008, 2006.

Central People's Government-PRC: National Guideline on Medium- and Long-Term Program for Food security (20082020), http://www.gov.cn/test/2008-11/14/content_1148698. htm, last access: 4 April 2008. 
Chivenge, P., Vanlauwe, B., and Six, J.: Does the combined application of organic and mineral nutrient sources influence maize productivity? A meta-analysis, Plant Soil, 342, 1-30, https://doi.org/10.1007/s11104-010-0626-5, 2011.

Cui, J., Zhang, R., Bu, N., Zhang, H., Tang, B., Li, Z., Jiang, L., Chen, J., and Fang, C.: Changes in soil carbon sequestration and soil respiration following afforestation on paddy fields in north subtropical China, J. Plant Ecol., 6, 240-252, https://doi.org/10.1093/jpe/rts023, 2012.

Dungait, J. A., Cardenas, L. M., Blackwell, M. S., Wu, L., Withers, P. J., Chadwick, D. R., Bol, R., Murray, P. J., MacDonald, A. J., Whitmore, A. P., and Goulding, K. W.: Advances in the understanding of nutrient dynamics and management in UK agriculture, Sci. Total Environ., 434, 39-50, https://doi.org/10.1016/j.scitotenv.2012.04.029, 2012.

Erb, K. H., Fetzel, T., Plutzar, C., Kastner, T., Lauk, C., Mayer, A., Niedertscheider, M., Korner, C., and Haberl, H.: Biomass turnover time in terrestrial ecosystems halved by land use, Nat. Geosci., 9, 674-682, https://doi.org/10.1038/NGEO2782, 2016.

Fischer, G., Van Velthuizen, H., Shah, M., and Nachtergaele, F. O.: Global Agro-ecological Assessment for Agriculture in the 21st Century: Methodology and Results, IIASA, Laxenburg, Austria; and FAO, Rome, Italy, 2002.

Gao, G., Wang, J., Li, S., and Pei, J.: Changes of organic carbon density and storage in northeastern black soil areas in past 30 years, Chinese J. Soil Sci., 46, 774-780, https://doi.org/10.19336/j.cnki.trtb.2015.04.002, 2015 (in Chinese with English abstract).

Gong, W., Yan, X. Y., Wang, J. Y., Hu, T. X., and Gong, Y. B.: Long-term manuring and fertilization effects on soil organic carbon pools under a wheat-maize cropping system in North China Plain, Plant Soil, 314, 67-76, https://doi.org/10.1007/s11104008-9705-2, 2009.

Gong, W., Yan, X. Y., and Wang, J. Y.: The effect of chemical fertilizer application on carbon input and export in soil - A pot experiment with wheat using natural ${ }^{13} \mathrm{C}$ abundance method, Geoderma, 189, 170-175, https://doi.org/10.1016/j.geoderma.2012.05.007, 2012.

Gurevitch, J., Curtis, P. S., and Jones, M. H.: Metaanalysis in ecology, Adv. Ecol. Res., 32, 199-247, https://doi.org/10.1016/S0065-2504(01)32013-5, 2001.

Han, G. Z., Zhang, G. L., Gong, Z. T., and Wang, G. F.: Pedotransfer functions for estimating soil bulk density in China, Soil Sci., 177, 158-164, https://doi.org/10.1097/SS.0b013e31823fd493, 2012.

Hansen, E. M., Munkholm, L. J., Olesen, J. E., and Melander, B.: Nitrate leaching, yields and carbon sequestration after noninversion tillage, catch crops, and straw retention, J. Environ. Qual., 44, 868-881, https://doi.org/10.2134/jeq2014.11.0482, 2015.

Hartmann, T. E., Yue, S., Schulz, R., Chen, X., Zhang, F., and Müller, T.: Nitrogen dynamics, apparent mineralization and balance calculations in a maize-wheat double cropping system of the North China Plain, Field Crop. Res., 160, 22-30, https://doi.org/10.1016/j.fcr.2014.02.014, 2014.

Hedges, L. V., Gurevitch, J., and Curtis, P. S.: The metaanalysis of response ratios in experimental ecology, Ecology, 80, 1150-1156, https://doi.org/10.1890/00129658(1999)080[1150:Tmaorr]2.0.Co;2, 1999.

Hijbeek, R., van Ittersum, M. K., ten Berge, H. F. M., Gort, G., Spiegel, H., and Whitmore, A. P.: Do organic inputs matter - a meta-analysis of additional yield effects for arable crops in Europe, Plant Soil, 411, 293-303, https://doi.org/10.1007/s11104016-3031-x, 2017.

Huang, S., Sun, Y. N., and Zhang, W. J.: Changes in soil organic carbon stocks as affected by cropping systems and cropping duration in China's paddy fields: A meta-analysis, Climatic Change, 112, 847-858, https://doi.org/10.1007/s10584011-0255-x, 2012.

Huang, S., Zeng, Y. J., Wu, J. F., Shi, Q. H., and Pan, $X$. H.: Effect of crop residue retention on rice yield in China: A meta-analysis, Field Crop. Res., 154, 188-194, https://doi.org/10.1016/j.fcr.2013.08.013, 2013.

IPCC: Land use, Land-Use Change, and Forestry, Cambridge University Press, Cambridge, 2000.

Ju, X. T., Liu, X. J., Zhang, F. S., and Roelcke, M.: Nitrogen fertilization, soil nitrate accumulation, and policy recommendations in several agricultural regions of China, Ambio, 33, 300-305, https://doi.org/10.1639/00447447(2004)033[0300:Nfsnaa]2.0.Co;2, 2004.

Karhu, K., Auffret, M. D., Dungait, J. A. J., Hopkins, D. W., Prosser, J. I., Singh, B. K., Subke, J.-A., Wookey, P. A., Agren, G. I., Sebastia, M.-T., Gouriveau, F., Bergkvist, G., Meir, P., Nottingham, A. T., Salinas, N., and Hartley, I. P.: Temperature sensitivity of soil respiration rates enhanced by microbial community response, Nature, 513, 81-84, https://doi.org/10.1038/nature13604, 2014.

Khan, S. A., Mulvaney, R. L., Ellsworth, T. R., and Boast, C. W.: The myth of nitrogen fertilization for soil carbon sequestration, J. Environ. Qual., 36, 1821-1832, https://doi.org/10.2134/jeq2007.0099, 2007.

Kong, A. Y. Y., Six, J., Bryant, D. C., Denison, R. F., and van Kessel, C.: The relationship between carbon input, aggregation, and soil organic carbon stabilization in sustainable cropping systems, Soil Sci. Soc. Am. J., 69, 1078-1085, https://doi.org/10.2136/sssaj2004.0215, 2005.

Kong, X. B., Lal, R., Li, B. G., Liu, H. B., Li, K. J., Feng, G. L., Zhang, Q. P., and Zhang, B. B.: Fertilizer Intensification and its Impacts in China's HHH Plains, in: Advances in Agronomy, edited by: Sparks, D. L., Academic Press, Burlington, USA, 135169, 2014.

Kong, X. B., Zhang, X. L., Lal, R., Zhang, F. R., Chen, X. H., Niu, Z. G., Han, L., and Song, W.: Groundwater Depletion by Agricultural Intensification in China's HHH Plains, Since 1980s, in: Advances in Agronomy, edited by: Sparks, D. L., Academic Press, Burlington, USA, 59-106, 2016.

Kuzyakov, Y. and Domanski, G.: Carbon input by plants into the soil, Review, J. Plant Nutr. Soil Sc., 163, 421-431, https://doi.org/10.1002/1522-2624(200008)163:4<421::AidJpln421>3.0.Co;2-R, 2000.

Ladha, J. K., Reddy, C. K., Padre, A. T., and van Kessel, C.: Role of nitrogen fertilization in sustaining organic matter in cultivated soils, J. Environ. Qual., 40, 1756-1766, https://doi.org/10.2134/jeq2011.0064, 2011.

Lal, R.: Soil carbon sequestration in China through agricultural intensification, and restoration of degraded and desertified ecosystems, Land Degrad. Dev., 13, 469-478, https://doi.org/10.1002/ldr.531, 2002. 
Lal, R.: Food security in a changing climate, Ecohydrology and Hydrobiology, 13, 8-21, https://doi.org/10.1016/j.ecohyd.2013.03.006, 2013.

Lehtinen, T., Schlatter, N., Baumgarten, A., Bechini, L., Kruger, J., Grignani, C., Zavattaro, L., Costamagna, C., and Spiegel, H.: Effect of crop residue incorporation on soil organic carbon and greenhouse gas emissions in European agricultural soils, Soil Use Manage., 30, 524-538, https://doi.org/10.1111/sum.12151, 2014.

Li, C. S., Zhuang, Y. H., Frolking, S., Galloway, J., Harriss, R., Moore, B., Schimel, D., and Wang, X. K.: Modeling soil organic carbon change in croplands of China, Ecol. Appl., 13, 327-336, https://doi.org/10.1890/10510761(2003)013[0327:Msocci]2.0.Co;2, 2003.

Liao, Y., Wu, W. L., Meng, F. Q., Smith, P., and Lal, R.: Increase in soil organic carbon by agricultural intensification in northern China, Biogeosciences, 12, 1403-1413, https://doi.org/10.5194/bg-12-1403-2015, 2015.

Liu, C., Lu, M., Cui, J., Li, B., and Fang, C.: Effects of straw carbon input on carbon dynamics in agricultural soils: A meta-analysis, Glob. Change Biol., 20, 1366-1381, https://doi.org/10.1111/gcb.12517, 2014.

Liu, S., Zamanian, K., Schleuss, P.-M., Zarebanadkouki, M., and Kuzyakov, Y.: Degradation of Tibetan grasslands: Consequences for carbon and nutrient cycles, Agr. Ecosyst. Environ., 252, 93 104, https://doi.org/10.1016/j.agee.2017.10.011, 2018.

Lohila, A., Aurela, M., Regina, K., and Laurila, T.: Soil and total ecosystem respiration in agricultural fields: effect of soil and crop type, Plant Soil, 251, 303-317, https://doi.org/10.1023/A:1023004205844, 2003.

Lu, F., Wang, X. K., Han, B., Ouyang, Z. Y., Duan, X. N., Zheng, H., and Miao, H.: Soil carbon sequestrations by nitrogen fertilizer application, straw return and no-tillage in China's cropland, Glob. Change Biol., 15, 281-305, https://doi.org/10.1111/j.13652486.2008.01743.x, 2009.

Luo, Z., Wang, E., and Sun, O.: Can no-tillage stimulate carbon sequestration in agricultural soils? A meta-analysis of paired experiments, Agr. Ecosyst. Environ., 139, 224-231, https://doi.org/10.1016/j.agee.2010.08.006, 2010.

MacDonald, B. H., Ross, J. D., Soomai, S. S., and Wells, P. G.: How information in grey literature informs policy and decisionmaking: A perspective on the need to understand the processes, Sixteenth International Conference on Grey Literature, Washington, DC, December, 2015.

Maillard, E. and Angers, D. A.: Animal manure application and soil organic carbon stocks: A meta-analysis, Glob. Change Biol., 20, 666-679, https://doi.org/10.1111/gcb.12438, 2014.

Meinshausen, M., Meinshausen, N., Hare, W., Raper, S. C., Frieler, K., Knutti, R., Frame, D. J., and Allen, M. R.: Greenhouse-gas emission targets for limiting global warming to $2^{\circ}$, Nature, 458, 1158-1162, https://doi.org/10.1038/nature08017, 2009.

Meng, F. Q., Dungait, J. A. J., Xu, X., Bol, R., Zhang, X., and $\mathrm{Wu}, \mathrm{W}$. L.: Coupled incorporation of maize (Zea mays L.) straw with nitrogen fertilizer increased soil organic carbon in Fluvic Cambisol, Geoderma, 304, 19-27, https://doi.org/10.1016/j.geoderma.2016.09.010, 2016.

Mikha, M. M., Rice, C. W., and Milliken, G. A.: Carbon and nitrogen mineralization as affected by drying and wetting cycles, Soil Biol. Biochem., 37, 339-347, https://doi.org/10.1016/j.soilbio.2004.08.003, 2005.

Ministry of Agriculture-PRC: National Modern Agriculture Development Plan (2011-2015), http://english.agri.gov.cn/hottopics/ five/, last access: 21 April 2013.

Ministry of Agriculture-PRC: Implementation Opinions of the Ministry of Agriculture on Conducting Campaign of Non-point Pollution Control, http://english.agri.gov.cn/governmentaffairs/ gaz/201506/t20150608_25790.htm, last access: 8 June 2015.

Mulumba, L. N. and Lal, R.: Mulching effects on selected soil physical properties, Soil Till. Res., 98, 106-111, https://doi.org/10.1016/j.still.2007.10.011, 2008.

National Agro-Tech Extension Center: Chinese Organic Fertilizer Handbook, Chinese Agricultural Press, Beijing, China, 1999 (in Chinese).

National Bureau of Statistics of China: Bulletin on the National Grain Output in 2016, http://www.stats.gov.cn/tjsj/zxfb/201612/ t20161208_1439012.html, last access: 12 August 2016.

Neff, J. C., Townsend, A. R., Gleixner, G., Lehman, S. J., Turnbull, J., and Bowman, W. D.: Variable effects of nitrogen additions on the stability and turnover of soil carbon, Nature, 419, 915-917, https://doi.org/10.1038/nature01136, 2002.

Pan, G., Li, L., Wu, L., and Zhang, X.: Storage and sequestration potential of topsoil organic carbon in China's paddy soils, Glob. Change Biol., 10, 79-92, https://doi.org/10.1111/j.13652486.2003.00717.x, 2003.

Pan, G. X., Xu, X. W., Smith, P., Pan, W. N., and Lal, R.: An increase in topsoil SOC stock of China's croplands between 1985 and 2006 revealed by soil monitoring, Agr. Ecosyst. Environ., 136, 133-138, https://doi.org/10.1016/j.agee.2009.12.011, 2010.

Power, A. G.: Ecosystem services and agriculture: tradeoffs and synergies, Phil. T. R. Soc. B, 365, 2959-2971, https://doi.org/10.1098/rstb.2010.0143, 2010.

Rosenberg, M. S., Adams, D. C., and Gurevitch, J.: MetaWin: Statistical Software for Meta-Analysis, Sinauer Associates, Sunderland, MA, USA, 2000.

Shi, T. T., Liu, Y. Q., Zhang, L. B., Hao, L., and Gao, Z. Q.: Burning in agricultural landscapes: An emerging natural and human issue in China, Landscape Ecol., 29, 1785-1798, https://doi.org/10.1007/s10980-014-0060-9, 2014.

Singh, M., Singh, V. P., and Reddy, D. D.: Potassium balance and release kinetics under continuous rice-wheat cropping system in Vertisol, Field Crop. Res., 77, 81-91, https://doi.org/10.1016/S0378-4290(01)00206-4, 2002.

Singh, S., Batra, R., Mishra, M. M., Kapoor, K. K., and Goyal, S.: Decomposition of paddy straw in soil and the effect of straw incorporation in the field on the yield of wheat, J. Plant Nutr. Soil Sc., 155, 307-311, https://doi.org/10.1002/jpln.19921550411, 1992.

Six, J., Conant, R. T., Paul, E. A., and Paustian, K.: Stabilization mechanisms of soil organic matter: Implications for C-saturation of soils, Plant Soil, 241, 155-176, https://doi.org/10.1023/A:1016125726789, 2002.

Smith, P.: Carbon sequestration in croplands: the potential in Europe and the global context, Eur. J. Agron., 20, 229-236, https://doi.org/10.1016/j.eja.2003.08.002, 2004.

Smith, P., Davies, C. A., Ogle, S., Zanchi, G., Bellarby, J., Bird, N., Boddey, R. M., McNamara, N. P., Powlson, D., Cowie, A., van Noordwijk, M., Davis, S. C., Richter, D. D., Kryzanowski, 
L., van Wijk, M. T., Stuart, J., Kirton, A., Eggar, D., NewtonCross, G., Adhya, T. K., and Braimoh, A. K.: Towards an integrated global framework to assess the impacts of land use and management change on soil carbon: current capability and future vision, Glob. Change Biol., 18, 2089-2101, https://doi.org/10.1111/j.1365-2486.2012.02689.x, 2012.

Soane, B. D.: The role of organic-matter in soil compactibility-a review of some practical aspects, Soil Till. Res., 16, 179-201, https://doi.org/10.1016/0167-1987(90)90029-D, 1990.

Song, G. H., Li, L. Q., Pan, G. X., and Zhang, Q.: Topsoil organic carbon storage of China and its loss by cultivation, Biogeochemistry, 74, 47-62, https://doi.org/10.1007/s10533-004-22223, 2005.

Tan, Y. C., Xu, C., Liu, D. X., Wu, W. L., Lal, R., and Meng, F. Q.: Effects of optimized $\mathrm{N}$ fertilization on greenhouse gas emission and crop production in the North China Plain, Field Crop. Res., 205, 135-146, https://doi.org/10.1016/j.fcr.2017.01.003, 2017.

Tian, K., Zhao, Y. C., Xu, X. H., Hai, N., Huang, B. A., and Deng, W. J.: Effects of long-term fertilization and residue management on soil organic carbon changes in paddy soils of China: A meta-analysis, Agr Ecosyst Environ, 204, 40-50, https://doi.org/10.1016/j.agee.2015.02.008, 2015.

Wang, J. Z., Wang, X. J., Xu, M. G., Feng, G., Zhang, W. J., and Lu, C. A.: Crop yield and soil organic matter after long-term straw return to soil in China, Nutr. Cycl. Agroecosys., 102, 371-381, https://doi.org/10.1007/s10705-015-9710-9, 2015.

Watson, R. T., Noble, I. R., and Bolin, B.: Land use, Land-Use Change, and Forestry: A Special Report of the Intergovernmental Panel on Climate Change, Cambridge University Press, Cambridge, 2000.

West, T. O. and Six, J.: Considering the influence of sequestration duration and carbon saturation on estimates of soil carbon capacity, Climatic Change, 80, 25-41, https://doi.org/10.1007/s10584011-0255-x, 2007.

Xu, C., Han, X., Bol, R., Smith, P., Wu, W. L., and Meng, F. Q.: Impacts of natural factors and farming practices on greenhouse gas emissions in the North China Plain: A meta-analysis, Ecol. Evol., 7, 6702-6715, https://doi.org/10.1002/ece3.3211, 2017.
Yan, X. Y., Cai, Z. C., Wang, S. W., and Smith, P.: Direct measurement of soil organic carbon content change in the croplands of China, Glob. Change Biol., 17, 1487-1496, https://doi.org/10.1111/j.1365-2486.2010.02286.x, 2011.

Yao, Z., Yan, G., Zheng, X., Wang, R., Liu, C., and ButterbachBahl, K.: Straw return reduces yield-scaled $\mathrm{N}_{2} \mathrm{O}$ plus NO emissions from annual winter wheat-based cropping systems in the North China Plain, Sci. Total Environ., 590/591, 174-185, https://doi.org/10.1016/j.scitotenv.2017.02.194, 2017.

Yu, Y. Q., Huang, Y., and Zhang, W.: Modeling soil organic carbon change in croplands of China, 1980-2009, Glob Planet. Change, 82/83, 115-128, https://doi.org/10.1016/j.gloplacha.2011.12.005, 2012.

Zhang, G., Lu, F., Zhao, H., Yang, G., Wang, X., and Ouyang, Z.: Residue usage and farmers' recognition and attitude toward residue retention in China's croplands, Journal of Agro-Environment Science, 36, 981-988, https://doi.org/10.11654/jaes.2016-1505, 2017 (in Chinese with English abstract).

Zhang, P., Wei, T., Jia, Z. K., Han, Q. F., and Ren, X. L.: Soil aggregate and crop yield changes with different rates of straw incorporation in semiarid areas of northwest China, Geoderma, 230, 41-49, https://doi.org/10.1016/j.geoderma.2014.04.007, 2014.

Zhang, X., Bol, R., Rahn, C., Xiao, G. M., Meng, F. Q., and Wu, W. L.: Agricultural sustainable intensification improved nitrogen use efficiency and maintained high crop yield during 1980 2014 in Northern China, Sci. Total Environ., 596/597, 61-68, https://doi.org/10.1016/j.scitotenv.2017.04.064, 2017.

Zhao, G. M., Miao, Y. X., Wang, H. Y., Su, M. M., Fan, M. S., Zhang, F. S., Jiang, R. F., Zhang, Z. J., Liu, C., Liu, P. H., and Ma, D. Q.: A preliminary precision rice management system for increasing both grain yield and nitrogen use efficiency, Field Crop. Res., 154, 23-30, https://doi.org/10.1016/j.fcr.2013.07.019, 2013.

Zhao, H., Sun, B. F., Lu, F., Zhang, G., Wang, X. K., and Ouyang, Z. Y.: Straw incorporation strategy on cereal crop yield in China, Crop. Sci., 55, 1773-1781, https://doi.org/10.2135/cropsci2014.09.0599, 2015. 